\title{
Inequality in Historical Perspective
}

\author{
Richard Jolly*
}

March 2006

\begin{abstract}
Adam Smith, Tom Paine, John Stuart Mill and Karl Marx were all bold and outspoken about the injustices of extreme inequality, nationally and internationally. Yet by almost every standard, global inequality has grown substantially since they were writing, and national income inequality also over the last two or three decades. There is a case today for more outspokenness about the extremes of inequality, both about the causes and how these causes are linked to extreme injustices in the past.
\end{abstract}

Keywords: income inequality, classical economists, United Nations JEL classification: B12, D31, 015

Copyright @ C UNU-WIDER 2006

*IDS, Sussex

This study is a revised version of the paper presented at the 17-18 June 2005 UNU-WIDER anniversary conference, 'WIDER Thinking Ahead: The Future of Development Economics', directed by George Mavrotas and Anthony Shorrocks.

UNU-WIDER gratefully acknowledges the financial contributions to the research programme by the governments of Denmark (Royal Ministry of Foreign Affairs), Finland (Ministry for Foreign Affairs), Norway (Royal Ministry of Foreign Affairs), Sweden (Swedish International Development Cooperation Agency_Sida) and the United Kingdom (Department for International Development). 


\section{Acknowledgements}

I thank Jaideep Gupte and Josie Furness for research assistance. We are grateful for help from the librarian and staff at the UN Library in Geneva. Any errors or misinterpretations are, of course, mine.

The World Institute for Development Economics Research (WIDER) was established by the United Nations University (UNU) as its first research and training centre and started work in Helsinki, Finland in 1985. The Institute undertakes applied research and policy analysis on structural changes affecting the developing and transitional economies, provides a forum for the advocacy of policies leading to robust, equitable and environmentally sustainable growth, and promotes capacity strengthening and training in the field of economic and social policy making. Work is carried out by staff researchers and visiting scholars in Helsinki and through networks of collaborating scholars and institutions around the world. www.wider.unu.edu publications@wider.unu.edu

UNU World Institute for Development Economics Research (UNU-WIDER)

Katajanokanlaituri 6 B, 00160 Helsinki, Finland

Camera-ready typescript prepared by Lorraine Telfer-Taivainen at UNU-WIDER

The views expressed in this publication are those of the author(s). Publication does not imply endorsement by the Institute or the United Nations University, nor by the programme/project sponsors, of any of the views expressed. 


\section{Introduction}

The magnitude of the increases in global inequality over the last two centuries are astounding, measured by both the absolute and the relative gaps between the richest and the poorest countries, and between the richest and the poorest groups of people. 1 Notwithstanding improvements in some indicators of global inequality in the last two decades due to the impressive expansion of China and India, the main indicators of global income inequality in recent years are all very high-and much higher than they appeared one or two hundred years ago. The trends can be seen in the estimates of the rise in Gini coefficients between 1820 and the 1990s, and of the increases in the gaps in per capita income between the highest 5 per cent and lowest 20 per cent of world population, shown in Tables 1 and 2.

Table 1: Global inequality

\begin{tabular}{lrrrrrrrrrrr}
\hline & 1820 & 1850 & 1870 & 1890 & 1910 & 1929 & 1950 & 1960 & 1970 & 1980 & 1992 \\
\cline { 2 - 10 } World Gini & 0.5 & 0.532 & 0.56 & 0.588 & 0.61 & 0.616 & 0.64 & 0.635 & 0.65 & 0.657 & 0.657 \\
World top 5\% to bottom 20\% & 7 & 7 & 9 & 10 & 12 & 12 & 15 & 14 & 16 & 18 & 16 \\
\hline
\end{tabular}

Source: Bourguignon and Morrison (2002: table 1).

Statistics on the trend in inequality within countries, shown in Table 2, reveal a more diverse picture. In the UK since the early nineteenth century, the ratio of the income shares of the richest and poorest steadily fell until about 1970, then remained level before rising sharply during 1977-89, with inequality rising more and faster than in any other OECD country. ${ }^{2}$ In the USA, inequality rose in the second half of the nineteenth century and declined over the twentieth, until the 1970s when they started increasing again. In the Scandinavian countries, inequality also rose somewhat over the last half of the nineteenth century and declined gradually but steadily during the twentieth-and have almost always been less than in the UK or the USA.

Inequality within developing countries over the long run is more difficult to judge, because of the severe scarcity and inadequacies of data for the nineteenth and the first half of the twentieth century. But after the Second World War, the ration of the shares between the richest and poorest groups are thought to have declined somewhat in China and India until about 1980 and increased after this, not only in China and India but also in many other developing countries. Inequality within Latin American countries was

\footnotetext{
1 As much emphasized recently, the relative gaps between the richest countries and China and India and a few other countries have narrowed in the last two decades or so, though inequality has grown within these and most other countries.
}

2 See, for instance, Atkinson (1999). 
already among the highest in the world and appears to have been rising in the last few decades. Although inequality in Africa (South Africa excepted) is generally not so extreme as in Latin America, the levels in many countries are high and also appear to be rising. But for sheer speed of increase, the rise in inequality in the countries in transition holds the record, following the collapse of the socialist model toward the end of the twentieth century.

Table 2: Inequality within countries and global inequality, 1820-1992, ratios of income of top $5 \%$ to bottom $10 \%$ within selected countries

\begin{tabular}{lrrrrrrrrrrr}
\hline & 1820 & 1850 & 1870 & 1890 & 1910 & 1929 & 1950 & 1960 & 1970 & 1980 & 1992 \\
\cline { 2 - 10 } USA & 13 & 13 & 18 & 25 & 25 & 20 & 13 & 13 & 12 & 12 & 15 \\
UK, Ireland & 40 & 40 & 35 & 30 & 30 & 16 & 10 & 10 & 7 & 7 & 10 \\
Scandinavian countries & 13 & 13 & 17 & 17 & 17 & 12 & 9 & 9 & 8 & 8 & 8 \\
Argentina, Chile & 16 & 16 & 16 & 16 & 16 & 16 & 16 & 16 & 16 & 22 & 23 \\
Cote d'Ivoire, Ghana, Kenya & 6 & 6 & 6 & 6 & 6 & 8 & 16 & 16 & 15 & 16 & 16 \\
Egypt & 16 & 16 & 16 & 16 & 16 & 16 & 16 & 16 & 15 & 15 & 15 \\
China & 14 & 14 & 14 & 14 & 14 & 13 & 9 & 8 & 8 & 10 & 12 \\
India & 12 & 12 & 12 & 12 & 12 & 12 & 10 & 10 & 10 & 9 & 8 \\
Japan & 12 & 12 & 12 & 12 & 12 & 14 & 6 & 6 & 6 & 6 & 6 \\
Brazil & 21 & 21 & 21 & 21 & 21 & 21 & 21 & 21 & 24 & 24 & 24 \\
\hline
\end{tabular}

Source: Bourguignon and Morrison (2002).

In considering these statistical trends over the last two centuries we need to bear in mind an important point made by Champernowne and Cowell (1998: 49). They warn against contemporary investigations that span very dissimilar cultures and which take in what has happened over very long periods. We cannot interpret quantitative comparisons of inequality across widely separated time periods or within a remote era without careful reference to the underlying social order then ruling. In short, as they summarize, 'Comparing communities in terms of inequality should not be performed in a vacuum; the study of the income distribution and related issues cannot ultimately be divorced from the historical development of the social and economic system.'

\section{Early views on inequality}

What did some of the early giants of political economy and political say about the issues of inequality, national and international? In contrast to today's often bloodless statistical analysis, where changes in a few decimal points are treated with reverence and as proof, the colour and lively description of political economists writing about inequality during the late eighteenth and early nineteenth centuries shines out, vividly and sharply.

Adam Smith (1976: 232) made some powerful comments about inequality and its origins; 'Wherever there is great property, there is great inequality. For one very rich 
man there must be at least five hundred poor, and the affluence of the few supposes the indigence of the many.' Smith emphasized the way such inequality led on to the need for government to maintain law and order; 'The affluence of the rich excites the indignation of the poor, who are often both driven by want, and prompted by envy, to invade his possessions. It is only under the shelter of the civil magistrate that the owner of that valuable property ... can sleep at night in security ... The acquisition of valuable and extensive property, therefore, necessarily requires the establishment of civil government.'

Smith had an evolutionary view of society and made clear how inequality had evolved with property. In the first period of society, the world of hunter-gatherers, there was little property, little inequality and seldom any regular administration of justice. ${ }^{3}$ The second period of society was the 'age of shepherds' and with this 'the inequality of fortune first begins to take place and introduces among men a degree of authority and subordination which could not possibly exist before. It thereby introduces some degree of civil government which is indispensably necessary for its own preservation' (Smith 1976: 23)

Smith though blunt, was measured. Thomas Paine (1995a: 401) writing two decades later, presented his analysis with pre-Marxian vitriol. He also focused on land as the source of inequality:

It is very well known that in England (and the same will be found in other countries) the great landed estates, now held in descent, were plundered from the quiet inhabitants at the conquest. The possibility did not exist of acquiring such estates honestly ... That they were not acquired by trade, by commerce, by manufactures, by agriculture or by any reputable employment is certain. How then were they acquired? Blush, aristocracy, to hear your origin, for your progenitors were Thieves ... When they had committed the robbery, they endeavoured to lose the disgrace of it, by sinking their real names under fictitious ones, which they called Titles. It is ever the practice of Felons to act in this manner.

By the mid nineteenth century, industrialization had advanced and poverty had deepened, especially in the towns in the United Kingdom. But the statistics suggest that little had changed in terms of income distribution. The income of the richest five per cent was still, on average, some 80 times estimated income per head. By this time, John Stuart Mill and Karl Marx had taken up the cudgels. Mill (1865: 260-1), though considering the acquisition of individual property through one's own labour as just, wrote damning indictments of the origins of the actual distribution of property in Europe at the time:

3 Anthropologists today would probably differ from this view. 
The social arrangements of modern Europe commenced from a distribution of property which was the result, not of a just partition, or acquisition by industry, but of conquest and violence: and notwithstanding what industry has been doing for many centuries to modify the work of force, the system still retains many and large traces of its origins. The laws of property have never yet conformed to the principles on which the justification of private property rests. They have made property of things which never ought to be property, and absolute property where only a qualified property ought to exist. They have not held the balance fairly between human beings, but have heaped impediments upon some, to give advantage to others; they have purposely fostered inequalities, and prevented all from starting fair in the race.

Mill goes on with analysis of the role of law in this process, which seems to have its own parallels today:

That all should start on perfectly equal terms is inconsistent with any law of private property; but if as much pains as has been taken to aggravate the inequality of chances arising from the natural workings of the principle, had been taken to temper that inequality by every means not subversive to the principle itself; if the tendency of legislation had been to favour the diffusion, instead of the concentration of wealth, to encourage the subdivision of the large masses instead of striving to keep them together; the principle of individual property would have been found to have no necessary connexion with the physical and social evils which almost all Socialist writers assume to be inseparable from it.

A half century later, or at least by the time of the eighth edition of his Principles of Economics, Alfred Marshall (1920) had considerably shifted the focus and frame of economic analysis. Although Marshall made the Distribution of the National Income the title and theme of Book VI, the final part of the Principles, his emphasis was very different from that of Mill and Marx. His unifying approach was the new science of marginal analysis applied to land and capital, as to other factors of production. Institutions of land and property were still there and of central importance, but little attention was given to close inquiry into their distant origins. 4 Although in appendices to the Principles, Marshall (1920: 647) showed himself well aware of the economic history of different parts of the world, including the role of war and conquest, he permitted himself this comment on the United States:

\footnotetext{
4 Although Marshall did include an Appendix A, which traced the growth of free industry and enterprise 'from savage life to the early forms of civilization'.
} 
Of the causes which have contributed to make the English race the chief owners of the New World, the most important is that bold enterprise which has made a man, who is rich enough to be a peasant proprietor, generally refuse to be content with the humdrum life and the narrow income of a peasant.

In spite of this paragraph being in a chapter on land tenure, there was no mention of the process under which millions of American Indians had been dispossessed of their land.

We need to jump ahead to the time of the United Nations to recover some of the blunt and colourful language of the early and mid nineteenth century economists. The 1951 UN report on Measures for the Economic Development of Underdeveloped Countries made much of the need for land reform, and reintroduced some of the early outspokenness. The expert committee included two subsequent Nobel Prize-winning economists, Arthur Lewis and T.W. Schultz. The report maintained the emphasis on how the land was owned and how it was used, not on how it was acquired. But there was quite enough to complain of in matters of landlord-peasant relationships:

In many under-developed countries, the cultivators of the soil are exploited mercilessly by a landlord class, which perform no useful social function. This class strives to secure itself the major part of any increase in agricultural yields, and is thus a millstone around the necks of the peasants, discouraging them from making improvements in agriculture and, in any case, leaving them too little income from which they might save to invest in the land. In such countries, land reform abolishing the landlord class is an urgent pre-requisite of agricultural progress. (UN 1951: 21)

In its early years, the UN returned to the issues of land reform on many occasions and in many reports. But over time, the language became more temperate and the emphasis shifted from distribution to the practicalities of raising agricultural productivity.

In the 1970s, income distribution within countries was again brought into focus with the ILO's World Employment Programme. The first of the ILO country missions, led by Dudley Seers to Columbia in 1970, made income distribution the centre of its analysis (ILO 1970). Within two years, redistribution from growth became the integrating core of the ILO mission to Kenya (ILO 1972). This led in 1974 to the joint World Bank-IDS study on Redistribution with Growth.5 generalizing strategies for linking growth with redistribution and providing case studies of experience in India, Cuba, Tanzania, Sri Lanka, South Korea and Taiwan.

5 Chenery et al. (1974). As made clear in the preface, it was Dudley Seers of the IDS who first proposed this collaborative effort. 
It is noteworthy that, until recently, the World Bank did very little on income distribution as is brought out in its history, The World Bank: Its First Half Century (Kapur et al. 1997). The major exception was during the presidency of Robert McNamara between 1968-81, though even this was short-lived. McNamara raised the issue of income distribution on a number of occasions in the early 1970s and highlighted 'Latin America's scandalous income and wealth disparities' in a major speech in Mexico City in 1972. But after this, the emphasis was shifted away from equity and towards 'the absolute poor' (Chenery et al. 1974: 239). It is therefore significant and welcome that the World Bank's World Development Report 2006 focused so clearly on income distribution (World Bank 2006).

\section{Early views on international inequality}

Smith is widely seen as the intellectual father of free trade and globalization and certainly, he was a major advocate and analyst of the benefits of freer trade. But he was also careful to indicate his belief that there were losers as well as gainers in the process. For instance, he refers to the discovery of America and that of a passage to the East Indies by the Cape of Good Hope as 'the two greatest and most important events recorded in the history of mankind', and he underlines their enormously positive consequences (Smith 1976: 141); 'By uniting in some measure, the most distant part of the world, by enabling them to relieve one another's wants, to increase on another's enjoyments, and to encourage one another's industry, their general tendency would seem to be beneficial.' But Smith was totally alert to the fact that not all would benefit and he continues, 'To the natives, however, both of the East and West Indies, all the commercial benefits which can have resulted from those events have been sunk and lost in the dreadful misfortunes which they have occasioned.' Smith was careful in analysing how the worst of the misfortunes reflected the imbalances of power of the time, adding 'At the particular time when these discoveries were made, the superiority of force happened to be so great on the side of the Europeans that they were enabled to commit with impunity every sort of injustice in those remote countries.'

Smith looked to the future, in words which should perhaps encourage broader perspectives among today's supporters of free trade; 'However, perhaps, the natives of these countries may grow stronger, or those of the Europe may grow weaker, and the inhabitants of all the different quarters of the world may arrive at that equality of courage and force which, inspiring mutual fear, can alone overawe the injustice of independent nations into some sort of respect for the rights of one another.' And for good measure he adds, 'But nothing seems more likely to establish this equality of force than that mutual communications of knowledge and of all sorts of improvements which an extensive commerce from all countries to all countries naturally, or rather necessarily, carries along with it.' (Smith 1976: 142). 
Over the years of the UN, the importance accorded to global inequality has fluctuated, with periods when it has been seen as an important international issue followed by periods when it has been virtually ignored. Even in its first few years, the UN's own work on national income raised concerns about income distribution within and between countries. In 1951 in the UN Economic and Social Council (ECOSOC), for instance, the Indian delegate noted that 'the average annual per capita income of North America was $\$ 1,100$, of Oceania \$560, of Europe \$380, of USSR \$310, of South America \$170, of Africa \$75, and of Asia only \$50. Thus, it appeared that the 65 per cent of the world's population which lived in Africa, Asia and Latin America received only about 15 per cent of the world's income.' 6

This stirred some surprising reactions. The delegate of the USSR made a strong attack on internal income distribution within the United States. More surprising, this was followed by the American delegate making supportive comments about the need to tackle global inequalities:

Everyone would agree ... that it was desirable to reduce and in due course to eliminate the existence of such large discrepancies ... that national and international action must be taken to secure a greater equality in living standards in the world. It was believed in the United States that the existing disparities in national income must be reduced by an expansion of the world's total income, an increasing share of that expanding income going to underdeveloped areas. The problem must be viewed dynamically in terms of increasing the world's volume of goods and services and in raising general well-being. ${ }^{7}$

The Brazilian delegate put the point with fewer qualifications: 'The problems was not to restore the old balance, but rather to create a new equilibrium by which the disparities of income and wealth throughout the world would be eliminated ...' 8 When ten years later, the First Development Decade was under preparation, the Proposals for Action prepared by the Secretariat had this to say:

It is true that the GA resolution lays down a precise quantitative target for the increase in aggregate incomes, and there is no similar quantitative target for changes in income distribution. We can, however, take it for granted that the 5 per cent growth target established by the resolution also implies that the increment in incomes thus achieved should be wisely used for the benefit of poorer sections of the population and should result in a degree of social progress which is at least in balance

6 ECOSOC, 514 ${ }^{\text {th }}$ meeting, 22 August 1951, para 56, page 320.

7 ECOSOC 516 ${ }^{\text {th }}$ meeting, 23 August 1951, paragraphs 60, 61.

8 ECOSOC, 247 ${ }^{\text {th }}$ meeting, 18 March, 1949. 
with the rise in aggregate national income. Normally, this would mean that the rise in aggregate income must be associated with an income distribution more equal, or at least not more unequal, than that at present. (UN 1962: 9)

In 1969, the Pearson Commission issued its report, Partners in Development, the first sentence of which emphasised the importance of global income distribution: 'The widening gap between the developed and the developing countries has become a central issue of our times' (Pearson 1969).

Concerns with global income distribution became more sharply focused in the 1970s with the North-South debate on the New International Economic Order (NIEO). Issues of global income distribution had been brought into sharp relief by the massive increases in oil prices, which had shifted the equivalent of about 2 per cent of global income in favour of the oil producing countries, with about three-quarters of this coming from developed countries and the remainder from developing countries. Fundamental questions were therefore raised about the links between international trade, economic relationships and global inequality, together with hopes that further changes might be possible. But such hopes were short-lived. Debate on the NIEO met with strong opposition from the industrial countries and was effectively terminated by the end of the 1970s. Rising debt and imbalances in budgets and foreign exchange in developing countries ushered in the era of stabilization and structural adjustment.

It took until 1988 before the UN General Assembly again came out strongly on global inequality:

Mindful that the existing inequalities and imbalances between the international economic system are widening the gap between developed and developing countries and thereby constitute of major obstacle to the development of the developing countries and adversely international relations and the promotion of world peace and security. 9

Though in the 1990s, UNDP's Human Development Reports frequently drew attention to global inequality, the dominant international focus in recent years has been on poverty and the Millennium Development Goals. Though this has certainly been a move in the right direction and a big improvement on economic growth as the central preoccupation for development, it is still far from sufficient. The Millennium Declaration itself made little reference to global inequality. Cornia (2004: 3) has summarized the positive and the negatives of recent developments:

9 United Nations, General Assembly GA/RES/43/156, 8 December 1988. 
The last decade has witnessed a blossoming of research on povertyrelated topics as well as a surge in attention towards the issue of poverty reduction by governments, the international financial institutions, the United Nations and social scientists ... [but he adds] A similar shift in focus and policy stance has yet to take place in the case of income inequality. While research in the field has made considerable strides, the policy reforms inspired by the Washington consensus have broadly ignored the issues of high and rising inequality, of its impact on poverty and growth, and of the measures required to contain it.

\section{Conclusions and recommendations}

Some of the greatest economists and philosophers of two centuries ago were bold and outspoken about the injustices of extreme inequality, nationally and internationally. Their words stand in sharp contrast to the more measured descriptions of analysts today. Yet by almost every standard, global inequality has grown substantially since that period, just as national inequality has grown in most countries over the last two to three decades. There is a case today for more outspokenness. There is also a case for more outspokenness about the causes of inequality, and how these causes are linked to some of the extreme injustices of the past. Moreover, some of the inequality are maintained by laws of property and economic relationships which do not readily allow for investigations into the distant origins of these inequality. Several examples come to mind:

- Inequalities of land holdings, mine or forest resources, where original ownership derived from colonial times. It is conventional among politicians of developed countries to say that the colonial era is past and no longer of relevance. Often national constitutions, put in place at the time of independence, prevent reopening issues of land ownership or only allow this if there is to be full compensation. Economists should be willing to remind such persons that the ownership of inherited property, and the continuing benefits of having had such property, often serve as a link with these injustices of the colonial past.

- Inequalities related to theft or the unjust allocation of new rights influenced by political connections. A particular source of current injustice relates to the acquisition of mining royalties through support for a new government seizing power through a coup or using other undemocratic means with foreign support, as with the recent attempt in Equatorial Guinea.

- The operation of legal systems and international law in the context of great inequality of wealth and disparities of power and political influence act as a force for sustaining and sometimes for increasing inequality. Again there are many examples but those in the area of intellectual property and trade are especially important for developing countries. 
For encouragement to think more courageously about international income redistribution, one can end by referring to the remarkable and bold proposal of Paine (1995b: 409-33) put forward in his pioneering pamphlet on Agrarian Justice in 1795-6. Paine began this proposal by commentating on the state of 'civilization', using language that if replaced with the word globalization could easily be applied today. He wrote that the inequality of the time were such that 'on the one side the spectator is dazzled by splendid appearances; on the other, he is shocked by extremes of wretchedness.'

This led to Paine's remarkable proposal for income redistribution published more than two centuries ago. He proposed a plan for ameliorating the situation of young and older persons by the creation in every nation of a national fund. This would be used to pay every young man and young woman at age twenty-one a sum of fifteen pounds sterling to enable that person to make a start in the world. Persons reaching the age of fifty would receive an annual pension of ten pounds. In both cases the logic was that in earlier times both groups would have had access to land to provide initial employment or security for their later years, but with the enclosure movement and dispossession of half the population from the land this was no longer available.

Paine's proposal for funding this scheme was equally remarkable. He proposed that an inheritance tax should be set at the level of 10 per cent of the value of all landed property and that this should be charged on the death of the owner, at the time the property passed to the next generation. Paine calculated that the revenue generated by this scheme would be sufficient in Britain and in France to fund the one-off payments to the young as well as the annual pensions to older persons. Some of the finer points of Paine's scheme also show him far ahead of his time: benefits would be paid equally to women and men; equally to rich as to the poor; and the scheme should apply to all countries. Moreover, in arguing for the inheritance tax, Paine kept it to 10 per cent, precisely because he recognized the important contribution that landowners had made in raising the productivity of their land, however unjustified the origins of their property. Incentives for landowners to continue to improve their land and raise productivity would remain.

If such imaginative and daring proposals could be put forward two centuries ago, when global inequality was much less and the difficulties of taking action appeared much greater, how much more should analysts today be inspired to think afresh. These bold and brave early pioneers should be today's inspiration, not only for analysing inequality but for exploring what can be done about it. 


\section{References}

Atkinson, A.B. (1999). 'Is Rising Inequality Inevitable? A Critique of the Transatlantic Consensus', Wider Annual Lectures 1999, UNU-WIDER: Helsinki. Reprinted in (2005) Wider Perspectives on Global Development, Palgrave Macmillan: Basingstoke.

Bourguignon, F., and C. Morrison (2002). 'Inequality Among World Citizens: 18201992’, The American Economic Review 92(4): 731-32.

Champernowne, D.G., and F.A. Cowell (1998). Economic Inequality and Income Distribution, Cambridge University Press: Cambridge.

Cornia, G.A. (ed.) (2004). Inequality, Growth, and Poverty in an Era of Liberalization and Globalization, Oxford University Press for UNU-WIDER: Oxford.

Chenery, H., M.S. Ahluwalia, C.L.G. Bell, J.H. Duloy, and R. Jolly (1974). Redistribution with Growth: Policies to Improve Income Distribution in Developing Countries in the Context of Economic Growth, Oxford University Press: London.

ILO (1970). Towards Full Employment: A Programme for Colombia, ILO: Geneva.

ILO (1972). Employment, Incomes and Equality: A Strategy for Increasing Productive Employment in Kenya, ILO: Geneva.

Kapur, D., J.P. Lewis, and R. Webb (1997). The World Bank: Its First Half Century, Brookings Institution Press: Washington DC.

Mill, J.S. (1865). Principles of Political Economy, Vol. 1, Longman, Roberts and Green: London.

Paine, T. (1995a, first published 1792). 'Dissertations on First Principles', in Rights of Man, Common Sense and Other Political Writings, Oxford University Press: Oxford.

Paine, T. (1995b, first published 1792) 'Agrarian Justice', in Rights of Man, Common Sense and Other Political Writings, Oxford University Press: Oxford.

Pearson, L.B. (1969). Partners in Development: Report of the Commission on International Development, Praeger: New York.

Smith, A. (1976, first published 1776). An Inquiry into the Nature and the Causes of the Wealth of Nations, Volume II, V, Part II, University of Chicago Press: Chicago.

UN (1951). Measures for the Economic Development of Underdeveloped Countries: Report by a Group of Experts Appointed by the Secretary-General of the United Nation, United Nations: New York.

UN (1962). The United Nations Development Decade: Proposals for Action, United Nations: New York.

World Bank (2006). World Development Report 2006, Equity and Development, Oxford University Press for the World Bank: Washington DC. 